\title{
TELAAH KRITIS PANDANGAN ULAMA DAYAH ACEH UTARA DAN ATURAN KHI TENTANG ATURAN PERKAWINAN POLIGAMI
}

\author{
Yusri Noval
}

\begin{abstract}
The issue of polygamy is a hot issue that to be debated continuesly. One side polygamy is claimed as exploitation and hegemony of male to female. On the other hand, polygamy is seen have normative reference and it considered as one of the solutions to solve the problems of in infidelity and prostitution. The Indonesian government has been reform the rules of polygamy. In KHI, although it adheres to the principle of monogamy, but the government is still open opportunity for polygamy. However, this rule of KHI is critized bythe dayah scholars of North Aceh. The overview of Ulama dayah is that polygamy rules made by the government out of the Shari'a corridors. Also that issueto be politicied and adopt the rules of the west to complicate polygamy practise and legalized prostitution. Therefor, this study aim to examine and analyze the rules of KHI regarding polygamy from sharia aspect, social, cultural, welfare and others. Also, analyze and critize the viens and thoughts of dayah scholar about the rules of polygamy in KHI.
\end{abstract}

\begin{abstract}
Abstrak: Masalah poligami adalah isu hangat yang terus diperdebatkan. Disatu sisi poligami dianggap sebagai bentuk eksploitasi dan hagemoni laki-laki terhadap perempuan. Sementara disisi lain, poligami dipandang mempunyai sandaran normatif yang tegas dan dianggap sebagai salah satu solusi untuk menyelesaikan permasalahan perselingkuhan dan prostitusi. Pemerintah Indonesia dalam hal ini telah mereformasi aturan-aturan poligami. Dalam KHI meskipun menganut asas monogami, namun pemerintah masih membuka ruang untuk berpoligami. Namun demikian, aturan ini menuai kritik dari ulama dayah Aceh Utara. Ulama dayah memandang bahwa aturan poligami yang dibuat oleh pemerintah keluar dari rambu-rambu syariat. Ditambah lagi tercium aroma politisasi dan mengadopsi aturan-aturan barat untuk mempersulit poligami sehingga menyuburkan praktik prostitusi. Oleh karenanya kajian ini mencoba menelaah dan menganalisa aturan-aturan dalam KHI mengenai poligami dari aspek syariah, sosial budaya, kemaslahatan dan lainnya. Sekaligus kemudian menganalisis secara kritis pandangan atau pemikiran ulama dayah tentang aturan poligami.
\end{abstract}

Keywords: Sosial, prostitusi, normative, pemerintah.

\section{Pendahuluan}

Isu poligami merupakan isu hangat yang terus diperdebatkan hingga saat ini. Disatu sisi poligami dianggap sebagai bentuk eksploitasi dan hagemoni laki-laki terhadap perempuan, poligami juga dituduh melanggar HAM (hak asasi manusia), bahkan poligami dituduh sebagai bentuk pelecehan terhadap martabat kaum perempaun kerana dianggap sebagai medium untuk memuaskan birahi semata. ${ }^{1}$ Namun dipihak lain poligami dikampanyekan kerana dipandang mempunyai sandaran normatif yang tegas, poligami justru mengangkat martabat kaum wanita dan dianggap

\footnotetext{
1 Siti Musdah Mulia, Islam Menggugat Poligami, PT. Gramedia Pustaka Utama, Jakarta, 2004, h. 43.
}

sebagai salah satu solusi untuk menyelesaikan permasalahan selingkuh dan prostitusi. ${ }^{2}$

Indonesia sendiri dalam hal ini telah melakukan reformasi terkait dengan ketentuan poligami. Meskipun berpegangan kepada asas monogami, namun tetap dibuka kemungkinan untuk poligami dengan syarat terlebih dahulu memohon izin dari Pengadilan. Pelaksanaan prosedur poligami diibaratkan 'menutup pintu yang terbuka', bermakna pintu poligami tidak dibuka apabila tidak diperlukan, hanya dalam keadaan

\footnotetext{
2 Ariij binti Abdur Rahman as-Sanan, Adil Terhadap Para Isteri: Etika Berpoligami, (Jakarta: Darus Sunnah Press, 2006), h. 36.
} 
tertentu saja pintu akan dibuka. ${ }^{3}$

Disisi lain ketentuan KHI tentang poligami juga mendapat sorotan dari kalangan ulama dayah Aceh Utara. Bersandarkan kepada pandangan ulama klasik ulama dayah mengkritisi regulasi poligami dalam KHI. Hal inilah yang kemudian menjadi polemik dalam masyarakat. Disatu sisi poligami diatur sedemikian rupa oleh Negara. Tapi disisi lain ulama menfatwakan bahwa ketentuan poligami yang diatur oleh Negara hanyalah aturan negara semata, bahkan sama sekali tidak memiliki landasan hukum syariat. Oleh karena itu tulisan ini mencoba menilai adakah butir-butir dalam KHI terkait dengan praktik poligami ini sudah sesuai dengan landasan syariat. Selain itu tulisan ini juga mencoba menganalisis serta mengkritisasi pandangan ulama dayah Aceh Utara tentang ketentuan poligami dalam KHI.

\section{Sejarah dan Kontroversi Praktik Poligami dari Masa ke Masa}

Berabad-abad sebelum Islam diwahyukan, masyarakat di berbagai belahan dunia telah mengenal dan mempraktikkan poligami. Di antaranya ialah Yunani, Persia, Mesir. kuno, Yahudi dan sebagainya. Masyarakat Jazirah Arab sendiri jauh sebelum Islam datang telah mempraktikkan poligami tanpa batas.

Beberapa faktor yang membuat praktik poligami tumbuh subur adalah adanya anggapan bangsa Timur kuno, seperti Babilonia, Madyan dan Syiria poligami merupakan suatu perbuatan suci karena para raja dan penguasa yang menempati posisi suci juga melakukan poligami. ${ }^{4}$ Selain itu, tirani dan dominasi (sistem partriakrkhi) serta perbudakan kaum pria terhadap kaum perempuan menjadi salah satu faktor pendorong poligami pada saat itu.

Namun, setelah Islam datang, poligami tidak serta merta dihapuskan. Nabi Muhammad melakukan perubahan sesuai dengan tuntunan dalam surat An-Nisa ayat 3, yaitu dengan membatasi jumlah bilangan isteri sampai dengan empat orang (limited polygamy) serta menetapkan syarat yang tambahan, yaitu harus mampu berlaku adil. ${ }^{5}$

\footnotetext{
3 Lia Noviana, "Persoalan Praktik Poligami dalam Masyarakat Islam,” Jurnal Salam, Vol. 15, No. 1 (2012), h. 85 .

${ }^{4}$ Musfir aj-Jahrani, Poligami dari Berbagai Persepsi, (Jakarta: Gema Insani Press, 1996), h. 28.

5 Murtadha Muthahari, Hak-hak wanita dalam Islam,
}

Masyarakat muslim pada awalnya mempraktikkan poligami lebih karena terpengaruh oleh sosial dan budaya yang berlaku pada masa itu. Ketika beberapa sahabat Nabi berpoligami, tidak lain ialah karena faktor budaya pada saat itu yang memandang lumrah terhadap poligami, bahkan membanggakannya. Justru monogami merupakan suatu hal di luar kebiasaan dan hanya sedikit orang yang melakukannya.

Di Indonesia, poligami mulai marak diperdebatkan sejak tahun 1911, yaitu ketika Kartini seorang figur perempuan Indonesia yang menulis penolakannya tentang bentuk perkawinan poligami. Dalam sebuah surat yang diterbitkan beberapa tahun setelah kematiannya Kartini menentang praktik poligami. Begitu pula di tahun 1928 dalam kongres perempuan pertama, para kelompok nasionalis perempuan menuntut adanya larangan praktik poligami. Di tahun 1930, Federasi Asosiasi Wanita Indonesia mengadakan pertemuan tentang poligami.

Selama sekitar 1300 tahun para ulama tidak pernah berbeda pendapat dalam hukum poligami (ta'addud al-zanjaat). Hingga pada abad $18 \mathrm{M}(13 \mathrm{H})$ tidak ada pro kontra mengenai bolehnya poligami dan semuanya sepakat bahwa poligami itu mubah (boleh). Sebab kebolehannya didasarkan pada dalil yang qathi (pasti). Para Imam yang empat, yakni Imam Abu Hanifah, Imam Malik, Imam Syafi'i, dan Imam Ahmad, juga sepakat bahwa poligami itu mubah. ${ }^{6}$

Para fuqaha berpendapat, bahwa Allah mengizinkan menikahi empat perempuan. Menurut mereka, walaupun kebolehan di sini ditambah dengan kondisi yang tidak mungkin ditunaikan, yaitu keadilan dalam kasih sayang, perasaan, cinta dan semacamnya. Namun, selama kemampuan berbuat adil di bidang nafkah dan akomodasi bisa ditunaikan, izin untuk berpoligami menjadi sesuatu yang bisa diperoleh. Alasan yang mereka kemukakan untuk mendukung ide ini adalah bahwa nabi sendiri pernah berkata hubungannya dengan ketidakmampuannya berbuat adil dalam hal kebutuhan batin.

(Jakarta: Lentera, 2001), h.257-258.

6 Abdurrhaman Al-Jaziry,al-Figh Ala Al-Madzabib Al-Arba' ah, Juz IV, (Beirut: DarulFikr, 1996), h. 206-217.

7 Khoiruddin Nasution, Riba dan Poligami, Sebuah Studi Atas Pemikiran MuhammadAbduh, (Yogyakarta: Pustaka Pelajar, 1996), h. 99. 
Demikian juga pendapat para Ulama tafsir (Mufassir), Al-Thabari (w. $310 \mathrm{H}$ ), yang berpendapat bahwa poligami adalah dibolehkan selama bisa berlaku adil. Demikian pula pandangan AlJashshash (w. $370 \mathrm{H}$ ) yang juga intensif mengupas tentang poligami. Beliau berpendapat bahwa poligami bersifat boleh (mubah), namun kebolehan ini harus disertai dengan syarat kemampuan berbuat adil di antara para istri, termasuk material, seperti tempat tinggal, pemberian nafkah, pakaian dan sejenisnya, serta kebutuhan non material, seperti rasa kasih sayang, kecenderungan hati dan semacamnya. Namun dia memberikan catatan, bahwa kemampuan berbuat adil di bidang non material ini amat berat

Sedangkan Al-Maraghi dalam tafsirnya menyebutkan bahwa poligami hanya diperbolehkan dalam keadaan darurat, misalnya karena isteri mandul, suami memiliki kemampuan seks yang tinggi sementara isteri tidak mampu melayaninya, suami mempuyai harta yang banyak untuk membiayai kepentingan keluarga dan jika jumlah perempuan melebihi dari jumlah laki-laki.

Berbeda dengan Ulama klasik, Ulama pada era modern dapat dikatakan memperketat kebolehan poligami, bahkan diantara mereka ada yang mengharamkannya. Meskipun di balik pengaharaman tersebut masih disertai dengan kondisi yang memberikan kemungkinan untuk melakukannya.

Terdapat beberapa alasan para pemikir modern melarang menikahi perempuan lebih dari satu, diantaranya Sayyid Quthb (w. 1966) mengatakan bahwa poligami merupakan rukbsah, danhanya dapat dilakukan dalam keadaan darurat serta harus bersikap adil dalam nafkah, mu 'amalah, pergaulan dan pembagian malam. ${ }^{8}$ Hal ini senada juga dinyatakan oleh Al-Shobuni. Sementara menurut Al-'Athar dengan ulasan yang agak diplomatis, mengatakan bahwa mengawini budak lebih ditekankan pada pemberian contoh pada umat lain bagaimana Islam memperlakukan tawanan, yaitu dengan mengawini mereka, yang lambat laun akan memerdekannya.

Namun demikian, Ameer Ali memberi catatan bahwa teori poligami digunakan jika suatu masyarakat yang menuntut adanya situasi yang menghendaki demikian, misalnya jumlah peremuan yang melebihi laki-laki. Dengan ungkapan yang

\footnotetext{
8 Sayyid Qutub, Tafsir fi dhilali al-Qur'an, Jil. IV(Kairo: Dar al-Kutub Al-Ilmiyah, 1961), h. 236.
}

berbeda Fazlur Rahman menyatakan kebolehan berpoligami merupakan suatu pengecualian karena keadaan tertentu, sebab kenyataannya kebolehan tersebut muncul ketika terjadi perang, di mana banyak anak yatim dan janda yang ditinggal suaminya. Sementara Muhammad Abduh menentang poligami karena dianggap menjadi sumber kerusakan di Mesir dan dengan tegas menyatakan bahwa tidak mungkin mendidik bangsa Mesir dengan pendidikan yang baik sepanjang poligami masih dipraktikkan secara luas.

Sedangkan menurut tokoh kontemporer, M. Syahrur membolehkan poligami dengan menetapkan adanya syarat kuantitas dan kualitasnya. Dari segi kuantitas, batas minimal poligami adalah satu perempuan, sedangkan batas maksimalnya adalah empat perempuan. Adapun syarat kualitasnya yaitu isteri kedua, ketiga, dan keempat yang boleh dinikahi harus janda yang memiliki anak-anak yatim yang kemudian menjadi tanggung jawabnya ${ }^{9}$

Begitu pula pendapat Asghar Ali Engineer, bahwa dalam surat An-Nisa : 3 lebih menekankan untuk berbuat adil terhadap anak-anak yatim, bukan mengawini lebih dari seorang perempuan. ${ }^{10}$ Karena konteks ayat ini adalah tentang kondisi pada masa itu, di mana mereka yang bertugas memelihara kekayaan anak-anak yatim sering berbuat tidak semestinya dan terkadang mengawininya tanpa mas kawin.

Seiring berkembangnya zaman, poligami mulai dianggap sebagai diskriminasi terhadap kaum perempuan. diantaranya muncul pendapt Amina Wadud yang berkesimpulan bahwa monogami merupakan bentuk perkawinan yang lebih disukai oleh Al-Qur'an. Dengan monogami tujuan perkawinan untuk membentuk keluarga yang penuh cinta kasih dan tentram dapat terpenuhi. ${ }^{11}$ Sependapat dengannya, Siti Musdah Mulia yang melontarkan penolakannya terhadap poligami karena laki-laki yang berpoligami pada prinsipnya adalah laki-laki yang mengumbar hawa nafsu nya dan poligami adalah selingkuh yang dilegalkan. ${ }^{12}$ Menurutnya, poligami merupakan kekerasan

\footnotetext{
9 M. Nashirudin, M.Ag-Sidik Hasan, M.Ag, Poros-poros Ilabiyah Perempuan Dalam Lipatan Pemikiran Muslim, (Surabaya : Jaring Pena, 2009), h. 249.

10 Asghar Ali Engineer, The Rights of Women in Islam (New York: St. Martin'sPress, 1992), h. 45.

${ }^{11}$ Amina Wadud Muhsin, Wanita di dalam Al-Qur'an, (Bandung : Penerbit Pustaka, 1994), h. 114.

12 Siti Musdah Mulia, Islam Menggugat Poligami, (Jakarta: PT. Gramedia Pustaka Utama, 2007), h. 61.
} 
pada perempuan karena berimplikasi pada sosiopsikologis. Dan sudah seharusnya diadakan revisi terhadap perundang-undangan perkawinan di Indonesia.

Secara garis besar, pandangan Ulama tentang praktik poligami, dapat digolongkan pada tiga pendapat, yaitu : Pertama, ulama klasik (AlThabari, Al-Jashshash dan Al-Qasimi), sepakat atas kebolehan poligami berdasarkan pada dalil qath'i dengan persyaratan mampu berlaku adil. Kedua, ulama modern (Sayyid Quthb, M. Abduh, Rasyid Ridha dan Mu'ammal Humaidi), berpendapat bahwa kebolehan poligami hanya dalam keadaan darurat dan mulai ada pembatasan poligami. Ketiga, ulama kontemporer (Asghar Ali Engineer, Amina Wadud dan Siti Musdah Mulia) menganggap bahwa poligami merupakan praktik ketidakadilan gender dan mengusulkan ketentuan sanksi hukum bagi para pelakunya.

\section{Pembaharuan Isu Poligami dalam Kompilasi Hukum Islam}

Indonesia sendiri dalam hal ini telah melakukan reformasi terkait dengan aturan poligami. Meskipun berpegangan kepada asas monogami, namun tetap dibuka kemungkinan untuk poligami dengan syarat terlebih dahulu memohon izin dari Pengadilan. Pelaksanaan prosedur poligami diibaratkan 'menutup pintu yang terbuka', bermakna pintu poligami tidak dibuka apabila tidak diperlukan, hanya dalam keadaan tertentu sahaja pintu akan dibuka. $^{13}$

Ketentuan tentang poligami dalam Kompilasi Hukum Islam (KHI) dibicarakan dalam BAB IX "beristeri lebih dari satu orang" dari pasal 55 sampai dengan pasal 59. Seseorang yang ingin berpoligami mestilah memiliki izin dari Pengadilan Agama ${ }^{14}$ serta terpenuhinya salah satu syarat alternatif ${ }^{15}$ dan tiga syarat kumulatif. ${ }^{16}$

${ }^{13}$ Lia Noviana, "Persoalan Praktik Poligami dalam Masyarakat Islam,” Jurnal Salam, Vol. 15, No. 1 (2012), h. 85 .

${ }^{14}$ Kompilasi Hukum Islam (pasal 56 ayat 1) "Suami yang hendak beristeri lebih dari satu orang harus mendapat izin dari Pengadilan Agama." Kata-kata harus dalam pasal terseebut bermakna lazim atau wajib.

${ }^{15}$ Syarat alternatif yang dimaksud adalah: a. Isteri tidak dapat menjalankan kewajipan sebagai isteri; b. Isteri mendapat cacat badan atau penyakit yang tidak dapat disembuhkan; c. Isteri tidak dapat melahirkan keturunan, Kompilasi Hukum Islam (pasal 57).

${ }^{16}$ Syarat kumulatif dalam prosedur poligami adalah adanya persetujuan dari isteri atau isteri-isteri, adanya kepastian
Bila dibandingkan dengan hukum fikih konvensional setidaknya terdapat dua hal dalam ketentuan KHI yang bersifat pembaharuan. Kelaziman meminta izin pengadilan (pengadilan) danharus mendapatkan izin dari isteri atau isteriisteri terdahulu.

\section{Analisis Pembaharuan Ketentuan Poligami dalam Kompilasi Hukum Islam}

Hampir dapat dipastikan bahawa poligami dalam pandangan mayoritas ulama klasik adalah dibolehkan. Dalam Al-Quran ataupun hadith tidak ada satu ketentuan pun yang secara tegas melarang amalan berpoligami, justru dalil-dalil menunjukkan kebolehan menikahi perempuan hingga empat orang. ${ }^{17}$ Namun demikian Islam telah berhasil membatasi dan mengatur perkawinan pada masa jahiliyah yang awalnya bebas dan tak terbatas, serta menetapkan asas keadilan dalam berpoligami. ${ }^{18}$

Pembaharuan tentang izin berpoligami secara eksplisit memang tidak ditemui dalam al-Quran maupun sunnah Nabi Muhammad Saw..Namun secara implisit hukumnya dapat ditemukan dari sumber dan dalil-dalil hukum Islam dengan melakukan ijtihad, penafsiran dan pemikiran hukum. ${ }^{19}$ Dalil menjadi pegangan untuk membolehkan amalan berpoligami adalah QS. AlNisa' ayat 3:

Maksudnya: "dan jikea kamu takut tidak berlaku adil terbadap perempuan-perempuan yatim (apabila kamun berkabwin dengan mereka), maka berkahwinlah dengan sesiapa yang kamu berkenan dari perempuanperempuan (lain): dua, tiga atau empat. Kemudian jike a kamu bimbang tidak akan berlaku adil (diantara isteri-isteri kamu) maka (berkabwinlah dengan) seorang sahaja, atau (pakaila) hamba-hamba perempuan yang kamu miliki. Yang demikian itu lebih dekat (untuk. mencegah) supaya kamu tidak. melakukan kerzaliman.

bahawa suami mampu menjamin keperluan hidup isteriisteri dan anak-anak mereka, Kompilasi Hukum Islam (pasal 58 ayat 1 huruf a dan b)

17 Muhammad ibn 'Ali ibn Muhammad al-Syawkani, Tafsir Fath al-Qadir:al-Jami' Bayn Fanni al-Riwayah wa al-Dirayah, (Libanon: Dar al-Ma’arif, tt), jilid I, 532; Muhammad ibn Yazid Abu 'Abd Allah, Sunan Ibn Majah, Tahqiq Muhammad Fuad 'Abd al-Baqi', (Beirut: Dar al-Fikr, tt.), jilid I, Hadith No 1952.

18 Ahmad Tholabie Kharlie, Hukum Keluarga Indonesia, (Jakarta: Sinar Grafika, 2013), h. 215.

19 Sudirman Tebba, Sosiologi Hukum Islam, (Yogyakarta:UUI Press, 2003), h. 87. 
Ayat ini menunjukkan menunjukkan boleh berpoligami dengan mensyaratkan berlaku adil kepada isteri-isteri. Adil yang dimaksudkan disini adalah keadilan secara lahiriyah, dari hal nafkah dan jatah bermalam. Bagaimanapun keadilan bathiniyah dari segi perasaan tidak akan dapat diwujudkan secara sempurna. ${ }^{20}$

Sebahagian ulama pula memandang ayat ini menjelaskan bahawa pada dasarnya asas perkawinan adalah monogami. Kebolehan melakukan poligami apabila boleh menjamin keadilan kepada isteri-isteri dapat dipenuhi dengan sebaiknya. ${ }^{21}$ Dilalah ayat pula menuntut kesiapan dari pelaku poligami. Kesiapan merupakan kondisi sekarang yang memperlihatkan kemampuan dimasa yang akan datang, baik dari segi psikis, moral maupun materi. ${ }^{22}$ Akan muncul pertanyaan, adakah keadilan ini merupakan tanggungjawab individu pelaku poligami yang pertanggungjawabannya langsung kepada Allah. Ataukah Pengadilan berhak campur tangan untuk menilai kesiapan seseorang?

Tentu syarat adil tidak cukup hanya dengan penilaian suami semata, yang pastinya akan berlaku penilaian yang subjektif. Ianya juga tidak sekedar tanggung jawab pribadi yang hanya dipertanggungjawabkan di hadapan Allah. Sudah semestinya dilakukan siasatan yang adil oleh hakim Pengadilan untuk menimbang keadilan seseorang. Pengadilan boleh menyelidiki dari sisi kemapanan ekonomi suami dan sikap serta tabiatnya melalui istrinya yang terdahulu dan juga orang-orang yang boleh dipercaya. $^{23}$

Sebenarnya, apa yang dilakukan Pengadilan merupakan usaha yang dilakukan oleh Pemerintah untuk memelihara kemaslahatan dalam rumah tangga. ${ }^{24}$ Selain itu, ketentuan undang-undang

${ }^{20}$ Ibrahim Hosen, Figh Perbandingan Masalah Pernikahan, (Jakarta: Pustaka Firdaus, 2003), h.138.

${ }^{21}$ Ahmad Rofiq,Hukum Islam di Indonesia, (Jakarta: Raja Grafindo Persada, 1998), cet. Ke 3, h.170.

${ }^{22}$ Mukti Ali Jalil, "Tinjauan Sosio Filosfis Urgensi Pemberian Izin Poligami di Pengadilan Agama", websiteBadan Peradilan Agama (badilag), dicapai 10 September 2014, http:/ /www.badilag.net/artikel/8685-tinjauan-sosiofilosofis-urgensi-pemberian-izin-poligami-di-pengadilanagama-oleh-mukti-ali-jalil-sag-mh--1910.html

23 Zaleha Muhamat, Analisis Poligami Menurut Perspektif Islam, (Kuala Lumpur: Utusan Publication \& Distributor Sdn. Bhd, 2002), h.19.

${ }^{24}$ Zulfahmi, "Metodologi Ijtihad Imam al-Shafi'i: Analisis Pembaharuan Berkaitan Aspek Munakahat di Malaysia" (Disertasi Sarjana Syariah, Universiti Malaya, Kuala Lumpur, 2011), h. 136. untuk poligami adalah untuk memberi kesan seseorang suami tidak akan sewenang-wenangnya berpoligami, karena kini pihak pengadilan akan memastikan kemampuan mereka sebelum permohonan poligami diizinkan.

Pada prinsipnya kebenaran atau izin dari Pengadilansesuai dengan prinsip-prinsip shariah. Dengan mengaplikasikan metode sadda zarai' pihak Pengadilan berhak melarang seseorang suami untuk berpoligami sekiranya gagal untuk membuktikan kemampuannya. ${ }^{25}$ Mengikut kaedah dar-ul mafaasid muqaddam 'ala jalbi al-mashalih, agar terhindar dari kerusakan (mafsadab) yang timbul akibat amalan berpoligami, maka Pemerintah berhak untuk menyelidiki kelayakan seorang yang ingin berpologami. Hal ini sesuai dengan prinsip tasharruf al-imam 'ala ra'iyah manuthun bil maslabah.

Secara formal, urgensi kebenaran dari Pengadilan untuk amalan berpoligami adalah demi terwujudnya kepastian hukum, ketertiban, perlindungan dan jaminan hukum atas perkawinan itu sendiri. ${ }^{26}$ Secara sosio-filosfis izin poligami adalah agar tercipta rumah tangga yang dapat menghidupkan nilai-nilai keadilan atas dasar mawaddah dan rahmah. Meskipun demikian kebenaran dari Pengadilan tidak serta merta menutup pintu poligami. Hanya saja penetapan ketentuanketentuan ini bertujuan demi ketertiban dan kemaslahatan bersama.

Selain izin dari Pengadilan disyaratkan juga izin dari isteri yang sedia ada untuk amalan berpoligami. Pengkaji menilai cukup Pengadilan saja yang menilai kelayakan suami berpoligami dengan segala pertimbangannya. Sebagaimana suami yang akan secara subjektif menganggap dirinya dapat berlaku adil, begitu juga isteri akan sangat sensitif dan subjektif dalam hal keizinan ini. Ditambah lagi tidak ditemukannya sandaran normatif terkait izin isteri sedia ada, baik itu dari al-Quran, hadith maupun pendapat-pendapat ulama.Selain itu sulitnya mendapatkan izin isteri yang ada menjadi sebab semakin banyak perkawinan poligami yang

${ }^{25}$ Raihanah Haji Abdullah, "Poligami di Malaysia, h. 170.

${ }^{26}$ Mukti Ali Jalil, "Tinjauan Sosio Filosfis Urgensi Pemberian Izin Poligami di Pengadilan Agama”, website Badan Peradilan Agama (badilag), dicapai 10 September 2014, http://www.badilag.net/artikel/8685-tinjauansosio-filosofis-urgensi-pemberian-izin-poligami-dipengadilan-agama-oleh-mukti-ali-jalil-sag-mh--1910. html 
llegal (tidak sesuai dengan prosedur). ${ }^{27}$ Dalam hal ini akan lebih tepat bilamana pihak isteri hanya diminta memberi pandangan bukan untuk meminta keizinannya.

\section{Analisis Respon Ulama Dayah Berkaitan Izin Berpoligami}

Ulama dayah merespon negatif terhadap pembaharuan dalam KHI terkait memohon izin poligami dari Pengadilan. Dalam hal ini mereka tidak setuju dengan mengemukakan argumentasi dan dalil yang berbagai. Poligami dipandang memiliki landasan atau dalil yang membolehkan. Secara tegas al-Quran menyatakan dalam Q.S. al-Nisa' ayat 3 '....menikahlah kamu dengan wanita-wanita yang kamu berkenan, dua, tiga dan empat.... Dalil ini dengan jelas menunjukkan kebolehan poligami, jadi jangan dipersulit. ${ }^{28}$ Secara logika, apa yang dihalalkan oleh sudah tentu mempunyai hikmahnya bagi manusia. Begitu juga poligami memiliki hikmah yang banyak..$^{29}$ Diantara hikmahnya adalah ghazirah (syahwat) suami ini dapat datang kapan sahaja. Sedangkan isteri pada masamasa tertentu tidak bisa melayani suami, seperti pada saat haid, wiladah (selepas melahirkan). Ini akan menjadi masalah nantinya. ${ }^{30}$

Di pandang dari sisi sejarah, ini juga merupakan sunnah nabi Muhammad Saw.. bukankah di dalam diri Rasulullah ada contoh yang sepatutnya kita teladani. Barang siapa yang membenci akan sunnahku, bukanlah bagian dari ummatku. Oleh kerananya poligami adalah sunnah nabi, jangan kita coba menghalangnya dengan menambahkan aturan-aturan untuk mempersulit. ${ }^{31}$

Selain itu, ketentuan dalam KHI untuk meminta kebolehan Pengadilan bagi amalan berpoligami dicuragai memiliki muatan politis. Peraturan ini perintah dari Isteri Presiden ke-2

${ }^{27}$ Muhammad Ja'far, Perkawinan Poligami dalam Masyarakat Pidie, (BandaAceh: LKIS-Unsyiah, 1998), h. 227.

${ }^{28}$ Tgk. H. Mustafa bin Tgk. H. Ahmat (Pimpinan Dayah Madinatuddiniyah Darul Huda, Paloh Gadeng, Aceh Utara) dalam temu bual dengan penulis, 3 Oktober 2014.

${ }^{29}$ Tgk. H. M. Amin Daud (Pimpinan Dayah Raudhatul Ma'arif, Cot Trueng, Aceh Utara) dalam temu bula dengan penulis, 22 Oktober 2014.

${ }^{30}$ Tgk. M. Yusuf Ilyas, (Pimpinan Dayah Darul Muridin, Bayu, Aceh Utara) dalam temu bual dengan penulis, 7 November 2014.

${ }^{31}$ Tgk. H. Muhammad Abduh Hasan (Pimpinan Dayah Darul Muttaqin, Samudera, Aceh Utara), dalam temu bual dengan penulis, 13 November 2014.
Indonesia, Soeharto. Dimana Ibu Tien (isteri pak Presiden) takut suaminya berpoligami, maka dibuatlah ketentuan ini. ${ }^{32}$ Ada juga ulama yang berpandangan bahawa ketentuan ini merupakan pengaruh dari Barat. Mereka ingin mempersulit poligami dan pada saat yang sama mereka menghalalkan tempat lokalisasi (prostitusi). ${ }^{33}$

Sebenarnya KHI dan ulama dayah sepakat bahawa poligami adalah mubah. Polemiknya adalah ketika izin dari pengadilan dianggap oleh ulama dayah sebagai usaha untuk mempersulit amalan poligami. Kita sepakat jika ini merupakan sunnah rasulullah Saw., dan telah diamalkan oleh para sahabat. Hanya saja memandangkan kepada realita sekarang praktik poligami yang melenceng dari tujuan. Terkadang poligami dilakukan mengikut nafsu semata. Kita juga sepakat tentang syarat 'adil' untuk berpoligami. Dalam Pengadilan pun, berusaha menyelidiki keadilan seseorang dari latar belakang kehidupannya, qarinah-qarinah (ciri-ciri) keadilan suami dan juga kehidupan rumah tangga yang sudah ada.

Anggapan dan kecurigaan bahwa ketentuan ini bermuatan politis dan pengaruh dari barat tidak dapat dibuktikan secara ilmiah. Bahkan jika kita perhatikan landasan penetapan hukum ini kita dapati tidak terkeluar dari jalur syariah. Aturan ini dibuat bukan untuk mempersulit amalan poligami, bahkan untuk memastikan amalan ini dilakukan oleh orang yang layak demi terwujudnya keluarga yang bahagia. Kita semua sepakat poligami untuk mendatangkan kebaikan pada semua, bukan malah sebaliknya untuk meruntuhkan institusi keluarga.

Dari perbahasan sebelumnya, dapat buat kesimpulan bahawa ulama dayah dalam hal ini masih berpegangan kepada pandangan-pandangan ulama salaf. Apa yang tidak pernah ditetapkan oleh ulama terdahulu tidak boleh ditambah. Padahal hukum itu sendiri tidak akan pernah sunyi dari perubahan persekitaran dan zaman.

\section{Penutup}

Polemik poligami tidak akan habis dimakan zaman. Ianya terus hidup dan berkembang seiring dengan perkembangan pemikiran manusia.

32 Tgk. Ramli Ben Cut, (Pimpinan Dayah Nurul Islam, Sawang, Aceh Utara) dalam temu bual dengan penulis, 17 Oktober 2014.

33 Tgk. Zakaria Amin, (Pimpinan Dayah Darul Arafah, Jamuan, Aceh Utara) dalam temu bual dengan penulis, 2 Desember 2014. 
Namun satu hal yang pasti tujuan dari setiap hukum yang disayariatkan adalah untuk kebaikan dan kemaslahatan umat. Termasuk poligami yang ditetapkan oleh Allah sudah dapat dipastikan adalah untuk memberi kebaikan kepada manusia. Oleh karenanya, Negara dalam hal ini membuat suatu regulasi yang mengatur sedemikian rupa terkait masalah poligami.

Adapun aturan yang ditetapkan dalam KHI memiliki landasan yang kuat dari dalil-dalil syariat. Juga dengan mengaplikasikan metode-metode pengambilan hukum ia nya tidak terkeluar dari jalur yang disyari'atkan. Begitupun ia memiliki tujuan yang baik demi mengawal amalan poligami ini tidak melenceng dari tujuan asal pensyariatan. Namun dalam ketentuan KHI terdapat poin yang harus dikaji lebih dalam, yaitu izin istri terdahulu.

Begitu pula para ulama, hendaklah lebih membaca real kondisi dalam masyarakat. Dimana Jika poligami dibebaskan secara luas, tanpa aturanaturan yang mengikat, maka ia hampir dapat dipastikan akan membawa kepada kemudharatan yang lebih besar. Wallabu a'lam.

\section{Daftar Pustaka}

Ahmad Rofiq,Hukum Islam di Indonesia, Jakarta: Raja Grafindo Persada, 1998, cet. Ke 3.

Ahmad Tholabie Kharlie, Hukum Keluarga Indonesia, Jakarta: Sinar Grafika, 2013.

Aj-Jahrani Musfir, Poligami dari Berbagai Persepsi, Jakarta: Gema Insani Press, 1996.

Al-Jaziry Abdurrhaman, al-Figh Ala Al-Madzabib Al-Arba' ah, Juz IV, Beirut: Darul Fikr, 1996.

Amina Wadud Muhsin, Wanita di dalam Al-Qur'an, Bandung: Penerbit Pustaka, 1994.

Ariij binti Abdur Rahman as-Sanan, Adil Terbadap Para Isteri: Etika Berpoligami, Jakarta: Darus Sunnah Press, 2006.

Asghar Ali Engineer, The Rights of Women in Islam, New York: St. Martin'sPress, 1992.

Ibrahim Hosen, Fiqh Perbandingan Masalah Pernikahan, Jakarta: Pustaka Firdaus, 2003

Khoiruddin Nasution, Riba dan Poligami, Sebuab Studi Atas Pemikiran Mubammad Abduh, Yogyakarta: Pustaka Pelajar, 1996.

Lia Noviana, "Persoalan Praktik Poligami dalam Masyarakat Islam," Jurnal Salam, Vol. 15, No. 1 (2012).
M. Nashirudin, M.Ag-Sidik Hasan, M.Ag, Porosporos Ilabiyah Perempuan Dalam Lipatan Pemikiran Muslim, Surabaya : Jaring Pena, 2009.

Muhammad ibn 'Ali ibn Muhammad al-Syawkani, Tafsir Fath al-Qadir:al-Jami' Bayn Fanni al-Riwayah wa al-Dirayah, Libanon: Dar alMa'arif, tt), jilid I,

Muhammad Ja'far, Perkawinan Poligami dalam Masyarakat Pidie, BandaAceh: LKISUnsyiah, 1998.

Muhammad ibn Yazid Abu 'Abd Allah, Sunan Ibn Majah, Tahqiq Muhammad Fuad 'Abd alBaqi', (Beirut: Dar al-Fikr, tt.), jilid I.

Mukti Ali Jalil, "Tinjauan Sosio Filosfis Urgensi Pemberian Izin Poligami di Pengadilan Agama", Website Badan Peradilan Agama (badilag), di akses 10 September 2014, http://www.badilag.net/artikel/8685tinjauan-sosio-filosofis-urgensi-pemberianizin-poligami-di-pengadilan-agama-olehmukti-ali-jalil-sag-mh--1910.html

Murtadha Muthahari, Hak-hak wanita dalam Islam, Jakarta: Lentera, 2001.

Raihanah Haji Abdullah, "Poligami di Malaysia," Jurnal Syariah 5, no. 2, 170.

Sayyid Qutub, Tafsirfi dbilali al-Qur'an, Jil. IV, Kairo: Dar al-Kutub Al-Ilmiyah, 1961.

Siti Musdah Mulia, Islam Menggugat Poligami, Jakarta: PT. Gramedia Pustaka Utama, 2004.

Sudirman Tebba, Sosiologi Hukum Islam, Yogyakarta:UUI Press, 2003.

Zaleha Muhamat, Analisis Poligami Menurut Perspektif Islam, Kuala Lumpur: Utusan Publication \& Distributor Sdn. Bhd, 2002

Zulfahmi, "Metodologi Ijtihad Imam al-Shafi'i: Analisis Pembaharuan Berkaitan Aspek Munakahat di Malaysia" Disertasi Sarjana Syariah, Universiti Malaya, Kuala Lumpur, 2011. 